\title{
Ultrastructure of Unikaryon nomimoscolexi n. sp. (Microsporida, Unikaryonidae), a parasite of Nomimoscolex sp. (Cestoda, Proteocephalidea) from the gut of Clarotes laticeps (Pisces, Teleostei, Bagridae)
}

\author{
Aminata Sene ${ }^{1}$, Cheikh Tidiane $\mathrm{Ba}^{1}{ }^{1}$ Bernard Marchand ${ }^{2}$, Bhen Sikina Toguebaye ${ }^{1, *}$ \\ 'Département de Biologie animale, Faculté des Sciences et Techniques, Université C.A. Diop de Dakar, Dakar, Sénégal \\ ${ }^{2}$ Observatoire Océanographique de Banyuls, Laboratoire Arago, B.P. 44, F-66651 Banyuls-Sur-Mer Cedex, France
}

\begin{abstract}
Unikaryon nomimoscolexi n. sp. was examined by electron microscopy from material collected in Senegal (West Africa). It parasitizes adult of Nomimoscolex sp. (Cestoda) from the gut of the freshwater fish Clarotes laticeps. The microsporidium is parasitic in parenchymal cells. All live cycle stages have isolated nuclei. Merogony and sporogony take place in direct contact with the host cell cytoplasm and ultimately give rise to unikaryotic sporoblasts and spores. The sporogony is disporoblastic. The spores are ovoid and measure, in thin sections, $3.43 \pm 0.4 \times 1.51 \pm 0.18 \mu \mathrm{m}$. The polaroplast has an anterior lamellar part and a posterior vesicular part. The polar tube is isofilar and is arranged in 6 to 8 coils
\end{abstract}

KEY WORDS: Unikaryon nomimoscolexi $\cdot$ Microsporida $\cdot$ Hyperparasite Nomimoscolex sp. Cestoda Clarotes laticeps $\cdot$ Pisces $\cdot$ Freshwater $\cdot$ Senegal

\section{INTRODUCTION}

Nomimoscolex sp. (Cestoda, Proteocephalidae) is an intestinal parasite of Clarotes laticeps (Teleostei, Bagridae) from freshwater of Senegal. While studying this parasite, we found that one adult was hyperparasitized by a microsporidium. In this report, this hyperparasite is described at the electron microscope level.

\section{MATERIAL AND METHODS}

A total of 23 specimens of Clarotes laciceps (Rüppell, 1829), a freshwater fish, were collected from Lake Guiers in Senegal and examined. Nomimoscolex sp. were removed from the intestine. A microsporidium

\footnotetext{
- Addressee for correspondence
}

was discovered during ultrastructural study of the spermiogenesis of this cestode. This hyperparasite is described at the electron microscope level

Small pieces of proglottids were fixed overnight in $2.5 \%(\mathrm{v} / \mathrm{v})$ glutaraldehyde in $0.1 \mathrm{M}$ sodium cacodylate buffer $(\mathrm{pH} 7.2)$ at $4^{\circ} \mathrm{C}$. After washing in buffer and post-fixation in $1 \%(\mathrm{w} / \mathrm{v})$ osmium tetroxide in cacodylate buffer for $1 \mathrm{~h}$ at $4^{\circ} \mathrm{C}$, the pieces were washed, then dehydrated in ethanol, cleared in propylene oxide and embedded in spurr resin. Ultrathin sections were cut on a Reichert-Jung ultramicrotome, stained with uranyl acetate and lead citrate and examined using a JEOL 100 CX II.

\section{RESULTS}

Stages of the microsporidium were found in the parenchymal cells (Fig. 1). 

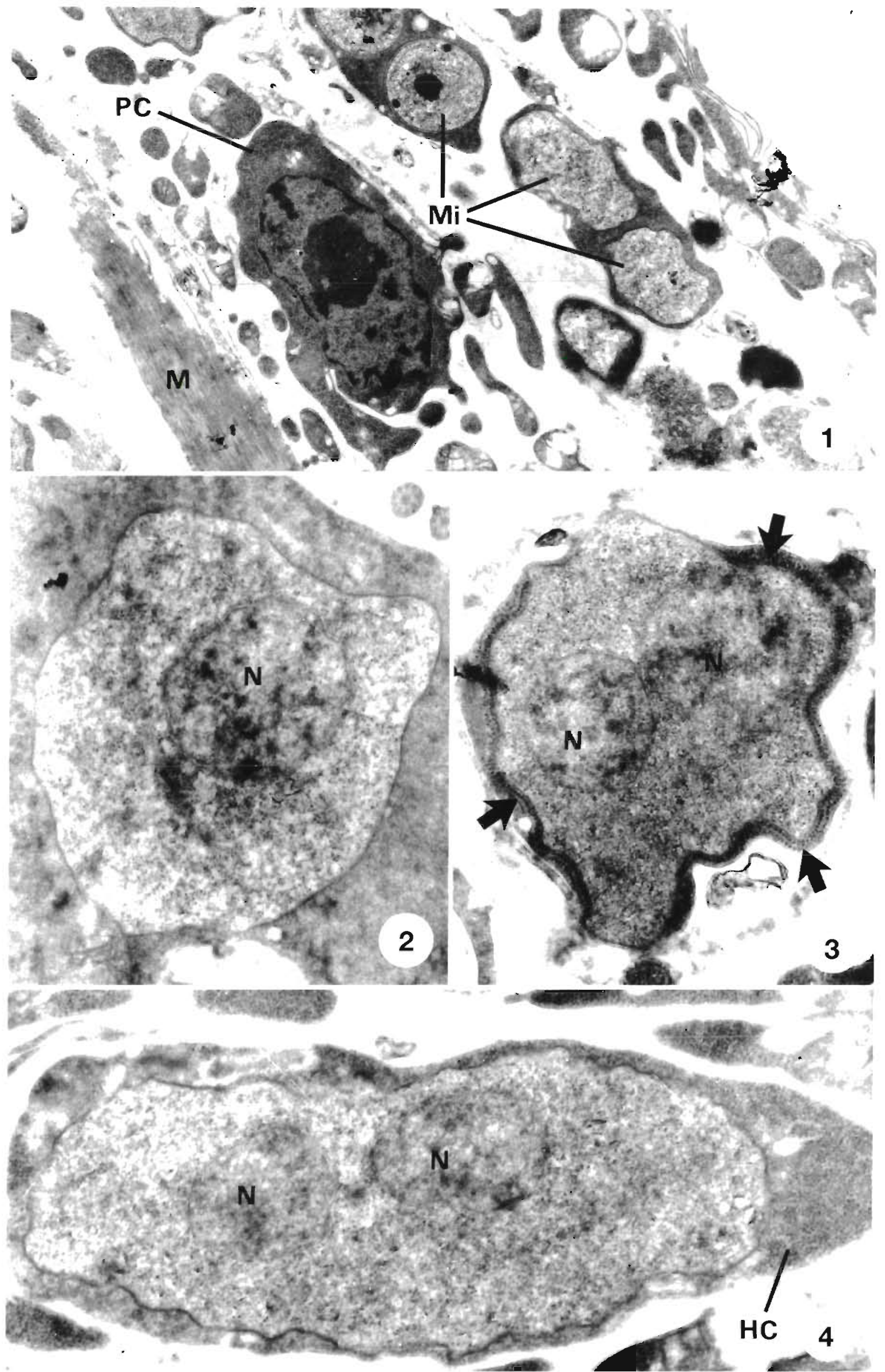
Figs. 1 to 4. Fig. 1. Ultrathin section of a parasitized zone of the host Nomimoscolex sp. parenchymal cells. M: muscle; Mi: microsporidium; PC: parenchymal cell $(\times 9500)$. Fig. 2. Uninucleate meront of the microsporidium. N: nucleus $(\times 20000)$. Fig. 3. Rounded binucleate meront. Note that the ribosomes of the host cell cytoplasm organise into bands (arrows) and surround the plasma membrane of the meront. N: nucleus $(\times 20000)$. Fig. 4. Elongate binucleate meront. HC: host cell; N: nucleus $(\times 15000)$

Meronts are uninucleate (Fig. 2) or binucleate (Figs. 3 \& 4). They are bounded by a thin surface membrane in direct contact with the host cell cytoplasm. Their cytoplasm contains numerous ribosomes and somes cisternae of endoplasmic reticulum. The nuclei are small, occupying a third of the width of the cells. Uninucleate meronts are spherical cells with irregular contours. Binucleate meronts are division stages; they are rounded with irregular contours (Fig. 3) or elongate (Fig. 4).

Sporonts (Fig. 5) differ from the meronts in possessing a thick electron-dense coat around the plasma membrane and a cytoplasm with a low ribosome content. Early sporonts are uninucleate, irregular or rounded but become binucleate and elongate (Fig. 5) before division into sporoblasts. Sporonts are in direct contact with the host cell cytoplasm.

Sporoblasts (Fig. 6) are produced by sporonts in pairs and differ from earlier stages in having a thick wall $(100 \mathrm{~nm})$ consisting of 2 electron-dense layers separated by an electron-lucent layer. The cytoplasm contains somes vacuoles. Sporoblasts become elongate, develop 6 to 8 coils of polar filament (Fig. 7) and an anchoring disc (Fig. 8). They are uninucleate and in direct contact with the host cell cytoplasm.

Mature spores are ovoid, uninucleate and in direct contact with the host cell cytoplasm (Figs. $9 \& 10$ ). A thin electron-dense exospore overlies the electron- lucent endospore, which is about $150 \mathrm{~nm}$ in thickness At the posterior end is a large vacuole containing electron-dense material (Fig. 9). At the anterior end is the anchoring disc which is eccentric in position (Figs. 10 \& 11). The polar tube follows in an oblique course from the anchoring disc through the polaroplast (Fig. 10). It is isofilar and has 6 to 8 coils arranged in a single or 2 layers beneath the spore wall (Fig. 9). The polaroplast consists of an anterior region of closely and electron-dense packed lamellae and a posterior region consisting of numerous small vesicles (Figs. 9 to 11 ). In thin sections, calculated spore dimensions are $3.43 \pm 0.2 \times 1.51 \pm 0.18 \mu \mathrm{m}(\mathrm{N}=21)$.

\section{DISCUSSION}

The microsporidium described herein belongs to the genus Unikaryon Canning, Lai \& Lie, 1974. The essential characters of this genus are disporoblastic sporogony, nuclei unpaired in all stages and development in direct contact with the host cell cytoplasm (Sprague et al. 1992). Since 1974, 11 species have been described and placed in this genus or have been transferred into it: U. piriformis Canning, Lai \& Lie, 1974; U. legeri (Dolfus, 1912) Canning \& Nicholas, 1974; U. allocreadii Canning \& Madhavi, 1977; U. exiguum Codreanu-

Table 1. Characteristics of Unikaryon spp. of platyhelminths

\begin{tabular}{|c|c|c|c|}
\hline Species & Hosts & Development stages & Source \\
\hline U. piriformis & $\begin{array}{l}\text { Echinoparyphium hystricosum } \\
\text { (Trematode from } \\
\text { aquatic gastropod) }\end{array}$ & $\begin{array}{l}\text { Spores: pyriform, } 3.8 \times 2.7 \mu \mathrm{m} \text { (fresh); } \\
3.4 \times 2.2 \mu \mathrm{m} \text { (fixed) } \\
\text { Polar filament: length } 150 \mu \mathrm{m}\end{array}$ & Canning et al. (1974) \\
\hline U. legeri & $\begin{array}{l}\text { Meigymnophallus minutus } \\
\text { (Trematode from } \\
\text { lamellibranch) }\end{array}$ & $\begin{array}{l}\text { Spores: ovoid, } 3.03 \pm 0.30 \times 1.76 \pm 0.02 \mu \mathrm{m} \text { (fresh); } \\
2.9 \pm 0.13 \times 1.66 \pm 0.24 \mu \mathrm{m} \text { (fixed) } \\
\text { Polar filament: } 6-6.5 \text { coils; length } 42-49 \mu \mathrm{m} \\
\text { Polaroplast: lamellar with } 2 \text { parts } \\
\text { Presence of a sporophorous vesicle }\end{array}$ & $\begin{array}{l}\text { Canning \& Nicholas } \\
(1974) ; \text { Azevedo \& } \\
\text { Canning (1987) }\end{array}$ \\
\hline U. allocreadii & $\begin{array}{l}\text { Allocreadium fasciatusi } \\
\text { (Trematode from } \\
\text { freshwater fish) }\end{array}$ & $\begin{array}{l}\text { Spores: ovoid, slightly asymmetrical } \\
\text { with one side flatter than the other, } \\
3.5 \pm 0.3 \times 2.7 \pm 0.2 \mu \mathrm{m} \text { (fresh) }\end{array}$ & $\begin{array}{l}\text { Canning \& Madhavi } \\
\text { (1977) }\end{array}$ \\
\hline U. slaptonleyi & $\begin{array}{l}\text { Echinoparyphium recurratum } \\
\text { (Trematode from } \\
\text { aquatic gastropod) }\end{array}$ & $\begin{array}{l}\text { Spores pyriform, } 5.01 \pm 0.2 \times 2.8 \pm 0.1 \mu \mathrm{m} \text { (fresh); } \\
4.6 \pm 0.3 \times 2.7 \pm 0.2 \mu \mathrm{m} \text { (fixed) } \\
\text { Polar filament: } 17-21 \text { coils; length } 145 \mu \mathrm{m}\end{array}$ & Canning et al. (1983) \\
\hline $\begin{array}{l}\text { U. nomimoscolexi } \\
\text { n. sp. }\end{array}$ & $\begin{array}{l}\text { Nomimoscolex sp. } \\
\text { (Cestode from freshwater fish) }\end{array}$ & $\begin{array}{l}\text { Spores ovoid: } 3.43 \pm 0.21 \times 1.51 \pm 0.18 \mu \mathrm{m} \text { (fixed) } \\
\text { Polar filament : } 6-8 \text { coils } \\
\text { Polaroplast: lamellar and vesicular }\end{array}$ & Present paper \\
\hline
\end{tabular}




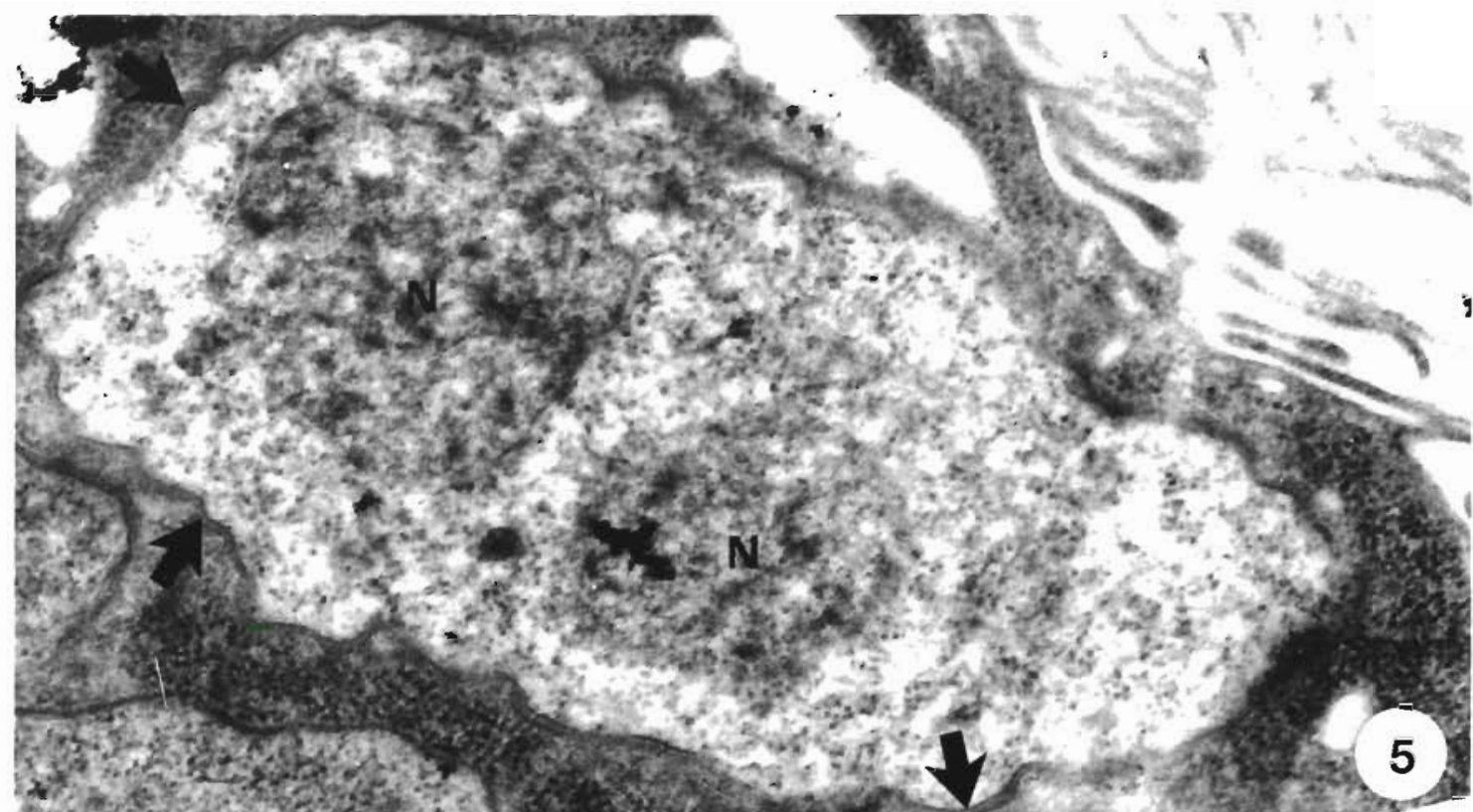
20.0.
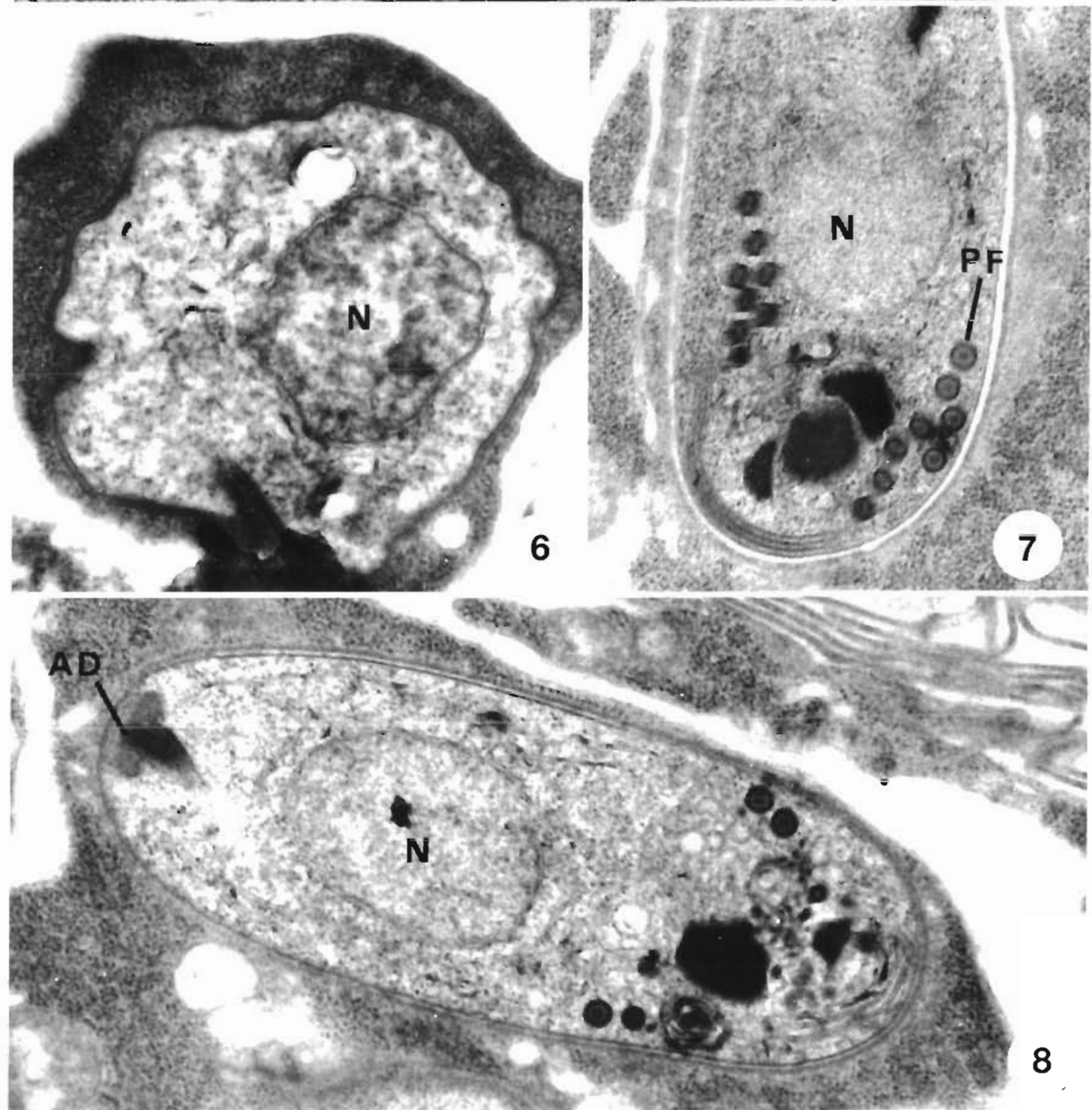
Figs. 5 to 8 . Fig. 5. Unikaryon nomimoscolei n. sp. Binucleate sporont with a thick wall (arrows). N: nucleus $(\times 20000)$ Fig. 6. Sporoblast. N: nucleus $(\times 20000)$. Fig. 7. Immature spore showing the well-formed polar tube $(\mathrm{PF})$. N: nucleus $(\times 25000)$. Fig. 8. Immature spore showing the anchoring disc (AD) of the developing polar tube. N: nucleus $(\times 25000)$

Balcescu, 1978; U. minutum Knell \& Allen, 1978; U mytilicolae Durfort, Vallmitjana \& Vivarès, 1980; $U$ slaptonleyi Canning, Barker, Hammond \& Nicholas, 1983; U. bouixi Toguebaye \& Marchand, 1983; U. matteii Toguebaye \& Marchand, 1984; U. euzeti Toguebaye \& Marchand, 1988; and U. nisotrae Toguebaye \& Marchand, 1989. U. arachnicolum Codreanu-Balcescu, Codreanu \& Traciuc, 1981 was transferred to the genus Oligosporidium (see Codreanu-Balcescu et al. 1981). Of these 11 species, only $U$. piriformis, $U$. legeri, $U$. allocreadii and $U$. slaptonleyi are parasites of platyhelminths (Canning et al. 1974, 1983, Canning \& Madhavi 1977. Sprague 1977, Azevedo \& Canning 1987). Comparison is only valid with these 4 species (Table 1) because $U$. exiguum and $U$. mytilicolae are found in crustaceans (Codreanu-Balcescu 1978, Durfort et al.
1980) and U. minutum, U. bouixi, U. matteil, U. euzeti and $U$. nisotrae parasitize coleopteran insects (Knell \& Allen 1978, Toguebaye \& Marchand 1983, 1984, 1988, 1989). Table 1 clearly shows that there are numerous discriminating characters for the species described here, i.e. host, environment and structure of spores.

A few microsporidia have been reported as parasites of cestodes (Sprague 1977), but of these only Nosema helminthorum Moniez, 1887 can be compared with the species described in this paper. $N$. helminthorum. parasitic in the tapeworm Moniezia expansa (Rudolphi, 1810), has 2 cycles of development corresponding to those of the genera Unikaryon and Nosema (see Canning \& Gunn 1984). The unikaryotic sequence produced meronts with large nuclei occupying at least two-thirds of the width of the cell, sporo-

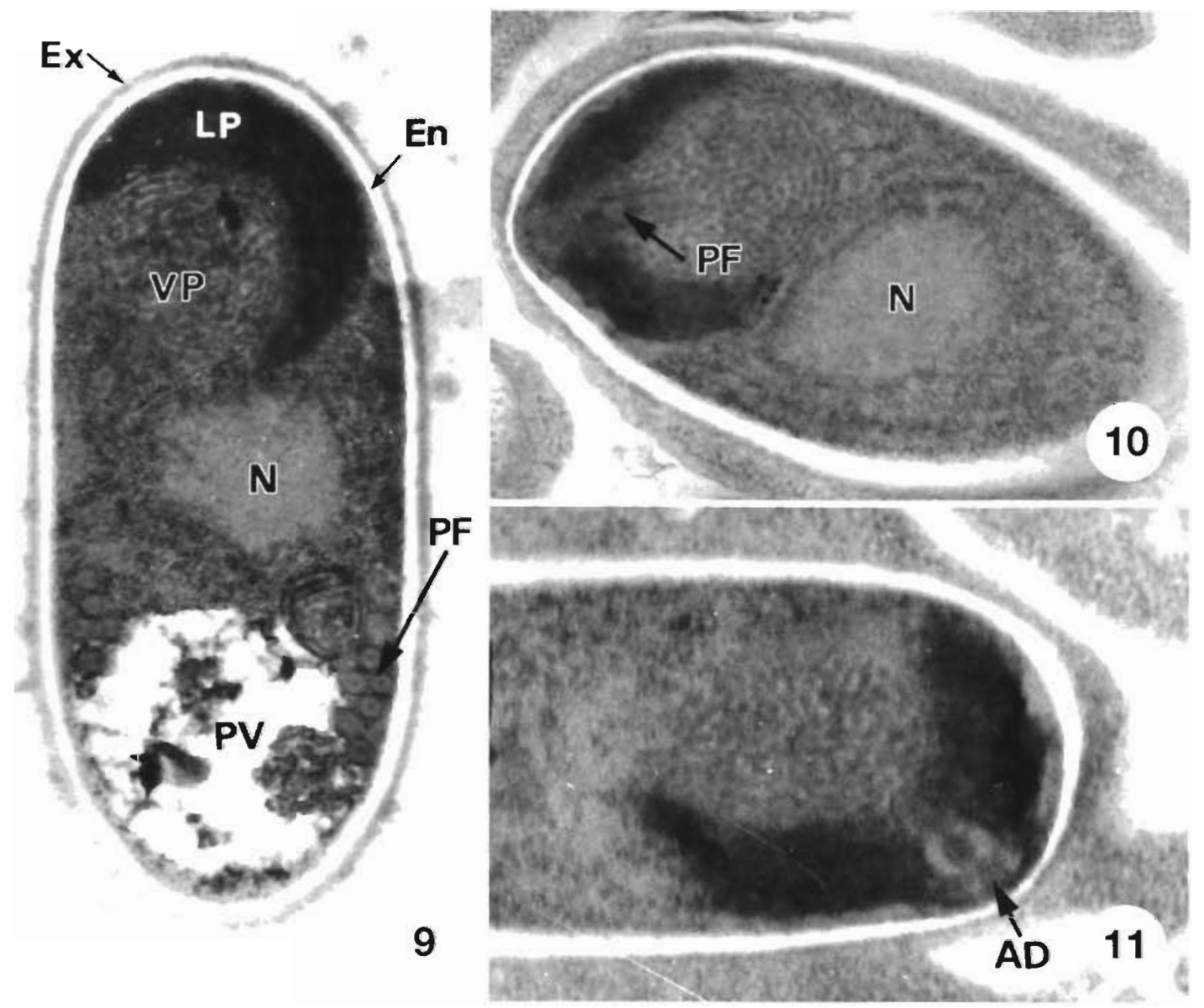

Figs. 9 to 11 Mature spores of Unikaryon nomimoscolei n. sp. AD: anchoring disc; En: endospore; Ex: exospore; LP: lamellar polaroplast; N: nucleus; PF: polar tube; PV: posterior vacuole; VP: vesicular polaroplast $(\times 35000)$ 
blasts having several concentric cisternae of endoplasmic reticulum around the nucleus and immature spores developing 5 to 8 coils of the polar filament (Canning \& Gunn 1984). The ultrastructural features of meronts, sporoblasts and young spores and the host of the present species are distinctive, and these differences are sufficient to justify its separation from $N$. helminthorum.

The microsporidium described in this study is undoubtedly a new species for which the name Unikaryon nomimoscolexi n. sp. is proposed.

There is no formation of sporophorous vesicles in Unikaryon nomimoscolexi but Unikaryon legeri, which also parasitizes a platyhelminth, does form sporophorous vesicles (Azevedo \& Canning 1987). It is not known whether Unikaryon piriformis, which is the type species of the genus, forms sporophorous vesicles. If it does, all Unikaryon species which develop in direct contact with the host cell cytoplasm should be transferred to a new genus; if not, a new genus should be created for $U$. legeri

\section{TAXONOMIC SUMMARY}

\section{Unikaryon nomimoscolexi n. sp.}

Type host: Nomimoscolexisp. (Cestoda, Proteocephalidea) from the gut of Clarotes laticeps (Pisces, Teleostei, Bagridae)

Type locality: Lake Guiers (Senegal, West Africa)

Merogony: Meronts are uninucleate or binucleate. They are bounded by a thin surface membrane in direct contact with the host cell cytoplasm. Binucleate meronts divide by binary fission.

Sporogony: Sporonts are in direct contact with the host cell cytoplasm and possess a thick electron-dense coat around the plasma membrane. Early sporonts are uninucleate but become binucleate and elongate before division into 2 uninucleate sporoblasts

Spores: Mature spores are ovoid, uninucleate and in direct contact with the host cell cytoplasm. Thin electron-dense exospore overlies the electron-lucent endospore, which is about $150 \mathrm{~nm}$ in thickness. At the posterior end is a large vacuole containing electrondense material. At the anterior end is the anchoring disc which is eccentric in position. The polar tube is isofilar and has 6 to 8 coils arrange in a single or 2 layers beneath the spore wall. The polaroplast consists of an anterior region of closely and electron-dense packed lamellae and a posterior region consisting of numerous small vesicles. In thin sections, calculated spores dimensions are $3.43 \pm 0.2 \times 1.51 \pm 0.18 \mu \mathrm{m}$.

\section{LITERATURE CITED}

Azevedo C, Canning EU (1987) Ultrastructure of a microsporidian hyperparasite, Unikaryon legeri (Microsporida), of trematode larvae. J Parasitol 73:214-223

Canning EU, Barker RJ, Hammond JC, Nicholas JP (1983) Unikaryon slaptonley sp. nov. (Microspora: Unikaryonidae), isolated from echinostome and strigeid larvae from Lymnea pregra: observations on its morphology, transmission and pathogenicity. Parasitology 87:175-184

Canning EU, Gunn A (1984) Nosema helminthorum Moniez, 1887 (Microspora, Nosematidae): a taxonomic enigma J Protozool 31:525-531

Canning EU, Lai PF, Lie JK (1974) Microsporidian parasites of trematode larvae from aquatic snails in West Malaysia. J Protozool 21:19-25

Canning EU, Madhavi R (1977) Studies on two new species of Microsporida hyperparasitic in adult Allocreadium fasciatus (Trematoda: Allocreadiidae). Parasitology 75 293-300

Canning EU, Nicholas JP (1974) Light and electron microscope observations on Unikaryon legeri (Microsporida, Nosematidae) a parasite of the metacercaria of Meigymnophalus minutus in Cardium edule. J Invertebr Pathol 23:92-100

Codreanu-Balcescu D (1978) Ultrastructural features of some microsporida infecting Artemia salina L. (Crustacea Anostraca) from Romania. Proc 4th Int Congr Parasitol, Warsaw, August, 1978, p 12-13

Codreanu-Balcescu D, Codreanu R, Traciuc E (1981) Ultrastructural data on a microsporidian infesting the ovaries of an araneid. J Invertebr Pathol 37:28-33

Durfort M, Vallmitjana L, Vivarès CP (1980) Unikaryon mytilicolae, hyperparasite de Mitilicola intestinalis: cycle évolutif et ultrastructure. J Protozool 27:77 A-78A

Knell JD, Allen GE (1978) Morphology and ultrastructure of Unikaryon minutum sp.n. (Microsporida : Protozoa) a parasite of the southern pine beetle, Dendroctonus frontalis. Acta Protozool 17:271-278

Sprague V (1977) Annotated lists of species of Microsporidia. In: Bulla LA Jr, Chena TC (eds) Comparative pathobiology, Vol 2. Systematics of the Microsporidia. Plenum Press, New York, p 31-334

Sprague V. Becnel JJ, Hazard EI (1992) Taxonomy of phylum Microspora. Critical Rev Microbiol 18:285-395

Toguebaye BS, Marchand B (1983) Développement d'une microsporidie du genre Unikaryon Canning, Lai et Lie, 1974 chez un Coléoptère Chrysomelidae, Euryope rubra (Latreille, 1807): etude ultrastructurale. Protistologica 19: $371-383$

Toguebaye BS, Marchand B (1984) Etude ultrastructurale de Unikaryon matteii n. sp. (Microsporida, Unikaryonidae) parasite de Nisotra sp. (Coleoptera, Chrysomelidae) et remarques sur la validité de certaines Nosema d'insectes. J Protozool 31:339-346

Toguebaye BS, Marchand B (1988) Cytologie et taxonomie d'une microsporidie du genre Unikaryon (Microspora, Unikaryonidae) parasite de Mylabris vestita (Coleoptera, Meloidae). Can J Zool 66:364-367

Toguebaye BS, Marchand B (1989) Etude en microscopie électronique des stades de développement d'Unikaryon nisotra n. sp. (Microspora, Unikaryonidae) parasite de Nisotra sjoestedti (Jacoby, 1903) (Coleoptera, Chrysomelidae). J Afr Zool 103:303-309 